San Jose State University

From the SelectedWorks of Michael L. Conniff

July, 2020

\title{
A Historiography of Populism and Neopopulism in Latin America
}

Michael L Conniff, San Jose State University 
A Historiography of Populism and Neopopulism in Latin America

\author{
Michael L. Conniff \\ Emeritus professor of history at San José State University
}

For over a half century, Latin American and other scholars have written reams and held innumerable conferences about the populist style of politics in the region. Historians quickly joined in with their theories, methods, and perspectives. Most literature focused on the classic period from the 1930s-1970s, when populism dominated many nations' governments. In the 1980s and 1990s, as the region rebounded from military dictatorship, new leaders using populist methods won office and instituted economic policies in line with neoliberalism. This reappearance, called neopopulism, sparked new interest in the subject. Finally, after 2000 numerous left-leaning politicians gave rise to a radical phase of neopopulism that lasted over a decade. This essay follows historians' and social scientists' work documenting and analyzing these phenomena.

Keywords: historiography, populism, neopopulism, Latin America, leftist neopopulism, neoliberalism, politics 
The term populism first arose with reference to Latin America in the 1950s and soon became broadly applied to many leaders, parties, movements, policies, and episodes. The phenomenon seemed to disappear during the military regimes of the $1960 \mathrm{~s}, 70 \mathrm{~s}$, and $80 \mathrm{~s}$, only to reappear in the 1990s in the guise of neo-populism. Over the decades the concept found frequent usage in Brazil, Venezuela, Argentina, Ecuador, Peru, Panama, Bolivia, and Mexico. Other countries' politics seemed resistant to its flourishing. The term continued to be employed in the 2010s but in such disparate ways that it may have outlived its usefulness as an intellectual category. This article provides an overview of histories of populism in Latin America during the past half century yet includes social science works that bear a resemblance to historical writings. I hope it is useful to graduate students seeking an introduction to the field.

Several caveats need stating. This review does not cover the earlier movements called populism in the United States and Russia, so-called right-wing populism in $21^{\text {st }}$ century Europe, or studies comparing them with Latin American variants. Further, it concentrates on writings by historians, though it does include sociologists and political scientists writing about countries where few historians took up the topic. This article does not look at biographies of figures called populists unless they explicitly focused on that aspect of their careers, nor does it include compilations of previously published essays. It assigns populism to four phases, the early or reformist (1904-1930), the classic (1934-66), the neo-populist (1986-2000), and the leftist neopopulist (2000-present). Finally, it selectively includes what I hope are the best works in a vast literature on the subject.

The first appearance of the term "populism" in print seems to have been by Hélio Jaguaribe (1954), referring to the long-time dominant figure in São Paulo, Adhemar de Barros, who called himself a populist in the late 1940s. Skidmore (1967) identified many other 
comparable leaders in Brazil's 1930-1964 era and developed a general definition that highlighted populists' prowess at winning elections, recruiting ever-larger followings, overcoming difficult challenges to their leadership, and creating auras of charismatic authority. He also associated these leaders with promoting “developmental nationalism." Political scientists Francisco Weffort (1965) and Octavio Ianni (1968) added their Marxist-leaning interpretations to Skidmore's historical findings (see below).

Torcuato DiTella (1965), a protégé of Gino Germani, expanded readers' attention to populism in several countries, especially his native Argentina, where Peronismo had been a force for two decades. He identified key aspects, such as populism's multi-class composition and reformist promise, and noted that some movements incorporated military elements. He analyzed the Peruvian APRA and Bolivian MNR as parties analogous to Peronismo. Other approaches emerged in these years. Victor Alba (1966), a labor historian, focused on the roles played by unions in the formation of national identity and anti-imperialist stances, two vibrant themes in the literature.

\section{0s}

The rise of military governments in these countries during the 1960s and 70s, partly a response to seemingly dangerous actions by the populists, brought an end to the classic phase. During the 1970s a few leaders bucked the trend, like Luis Echeverría in Mexico and Juan Perón in Argentina, but they soon succumbed. Still, the historical literature on populism grew rapidly during these years, embracing some previously overlooked countries like Bolivia, Ecuador, and Colombia (Mitchell, 1977, Martz, , Dix, 1978) and approaches like economic policy (Skidmore, 1978). Guillermo O'Donnell (1973) took a different tack, defining populism as an improvised response to the breakdown of authority (a hegemonic crisis according to him and others) in the 
1930s. He believed that the military governments of the 1960s, that he called bureaucraticauthoritarian, constituted an innovation because of their claims that populists had caused intolerable instability and that only the military could produce economic development under controlled circumstances.

O’Donnell fit into an Argentine school of populism studies that arose in the 1970s. In addition to DiTella, the group included Miguel Murmis and Juan Carlos Portantiero (1972), who shifted the focus of studies of Peronismo. First, they looked at the impact of the of industrial relations in the 1930s with an eye to tracing sociopolitical shifts during the década infame and how they foreshadowed the rise of a strong state to mediate among powerful actors. Second, they argued that workers responded to the appeals of their leader regardless of whether their unions were old or recent. Earlier authors had said that members of older unions resisted Perón's entreaties.

A Brazilian school also emerged during the middle years of dictatorship, drawing on earlier studies. Stalwarts Jaguaribe (1974), Ianni (1975), and Weffort (1978) published compilations of their earlier works, with enhancements. They were joined by new voices like Brito (1978), Andrade (1979), Debert (1979), and Camargo (1979). These writers decried the populist episode (sometimes called a republic) as a betrayal of the working class. Populists had posed as supporters of the downtrodden and promised reforms to benefit them, yet they had lied, manipulated, stolen, and abused their powers without delivering the ultimate promise, a workers' state. In the end they brought on the military occupation and the curtailment of workers' rights. The military also crushed the legitimate left and drove many into exile. It was a sorry legacy. Cardoso and Faletto (1979) seconded anti-imperialism as an element of their dependency theory yet saw populism as a manipulative device by which elites coopted leaders and their 
followers, an opportunistic paternalism allied with the impetuous masses. Ernesto Laclau (1977), drawing on the writings of Antonio Gramsci, took a Marxist approach to describing populism thus: "the presentation of popular-democratic interpelations as a synthetic-antagonistic complex with respect to the dominant ideology." (pp. 172-173) He emphasized discourse analysis to gauge interactions among sociopolitical sectors and included Nazism, Maoism, and Castroism as analogous phenomena. He later (1987) clarified that populism should not labeled negative but rather the result of disjointing, organization, and politicization. The first severed the links between the people and the elite, the second built new connections between them, and the third led to new governmental and social institutions.

Several Mexican scholars sought out populist trends in their society. Basurto (1969) found that Lázaro Cárdenas had achieved breakthroughs in politics by defeating the army generals using worker and peasant organization for electoral gains and mass mobilization. His achievements were comparable with those of Perón and Vargas in later decades. Redclift's (1980) study on the via campesina found populist movements among farmers to be quite improbable, given their disparate elements and the rise of global markets. Sanderson (1981) took the unusual approach of examining land policies in the northwest for elements of populism. Generally, however, Mexico has provided infertile ground for populism histories.

\section{0s}

Soon more historians weighed in on the subject, especially in Brazil, Argentina, Peru, and Ecuador, by nationals, U.S., and European scholars. French`s $(1988,1989)$ meaty articles analyzed labor politics and the rise of populism in São Paulo. Soares (1982) studied the emergence of a robust populist movement in Pernambuco, led by Miguel Arraes. Perruci \& 
Sanderson (1989) charted the meteoric rise of Collor de Mello in Brazil. Lars Schoultz (1983) analyzed statistics on voting behavior during the critical years when Perón gained ascendancy. In these years several Stanford history graduates published books on populism in Chile, Peru, and Brazil (Drake, 1978, Stein, 1980, Conniff, 1981) and later assembled a reader entitled, Latin American Populism in Comparative Perspective, (Conniff, 1982). Drawing on Skidmore, DiTella, and others, and incorporating historians working on Argentina, Mexico, and Venezuela, they assembled chapters on these nations and devised an introduction and conclusion that offered a historical definition of populism. They emphasized its multi-class makeup, charismatic leadership, reformism, electoral expansion, and appeal to popular culture. They also identified countervailing trends like strong parties that impeded populism from flourishing and speculated on the death of the phenomenon due to military dictatorships then prevalent in South America.

The Stanford graduates' reader broke populism into two phases, one they called reformist that emerged in the Southern Cone in the early twentieth century and a classic one spanning the 1930s to the 1960s. The first period saw the rise of four figures, José Batlle y Ordóñez in Uruguay, Hipólito Yrigoyen in Argentina, Arturo Alessandri in Chile, and Guillermo Billinghurst in Peru. These presidents pioneered electoral politics that loosely fit the definition they conceived. The second phase included more famous leaders, like Lázaro Cárdenas in Mexico, Juan Perón in Argentina, Rómulo Betancourt in Venezuela, and Getúlio Vargas in Brazil. These latter presidents took advantage of electorates much larger than their predecessors' as well as newly available transportation and communications media. The classic populists intensified the pace and breadth of campaigning compared to the earlier leaders and helped expand the electorates. 
Some theoretical wrinkles got smoothed out in those years. Mouzelis (1985) compared the modes of incorporation in Latin America and the Balkans, hypothesizing that the two main ways of expanding the electorate were clientelism and populism. In the latter, initiative gravitated to the leader, whose charisma bridged the space occupied by intermediaries in clientelist systems. Klaiber (1989) took the unusual approach of looking at the role of liberation theology in populism, through its creation of base communities that could be tapped by politicians. James (1985), studying class structure and Peronism, applied Antonio Gramsci’s approach to gauge the role of culture, common sense, and practical consciousness in the labor movement. Brazilian social scientists assembled many papers on populism and media, in Mello (1981).

By the late 1980s, three major shifts influenced the course of populism studies: the end of the military regimes, the fall of the USSR, and the reappearance of populism under new guises. With the reemergence of Brazilian populists Miguel Arraes, Jânio Quadros, and Leonel Brizola, it seemed that the classic era might not have ended after all. The armed forces, largely repudiated by their societies, could no longer object to the populists and indeed went on the defensive against prosecution for atrocities and "antipolitical" excesses. And the fall and breakup of the USSR altered the tenor of populism studies. Marxist approaches gradually waned as that ideology lost relevance in the post-Cold War era. Meanwhile, the rise of newcomer presidents like Alan García and Alberto Fujimori in Peru, Fernando Collor de Mello in Brazil, and Carlos Menem in Argentina led writers like Carrizo de Muñoz (1990) and Viguera (1993) to coin the term neopopulism.

\section{0s}


In view of these developments, the authors of Latin American Populism met in 1991 to discuss composing a new edition to bring their chapters up to date and to include fresh voices. They agreed that neopopulism represented the rebirth of classic populism, with adjustments for global changes underway. They also determined to jettison earlier chapters on the United States and Russia as too far removed from the Latin American experience. Next, they decided to stretch out their narratives to cover the entire twentieth century. They added new chapters on Panama and Ecuador, based on dissertation research, and one by Kurt Weyland on the compatibility of neoliberal economics and resurgent populism in the 1990s.

The new reader, Populism in Lain America (Conniff, 1999), filled in some earlier gaps in the populism story and focused on its 1990s rebirth. The new introduction traced the evolving conceptualization of populism over the twentieth century, looked at the contexts in which it arose and prospered, and examined the impact of new technologies on the conduct of politics. It reproduced DiTella's diagrams showing the structural formation of various parties in the region, with Peronismo clearly the predominant model. Finally, it presented electoral turnout data for 10 nations over the 1900-1994 period, revealing huge increases in voting to near saturation levels in most countries, largely as a result of populist recruitment and mobilization.

The new reader contained chapters on Argentina into the second Menem administration, Brazil through Collor de Mello's impeachment, Chile to the Christian Democratic Ruiz-Tagle administration, Mexico into the Zedillo government, Peru through the first Fujimori presidency, Venezuela to the eve of the Chávez election, Ecuador through the overthrow of Abdalá Bucarám, Panama to the presidential campaigns of Arnulfo Arias's widow, and Weyland's on the affinities of neoliberalism and neopopulism. Finally, the editor added an epilogue to explore potential new 
areas of historical research — the leader-follower nexus, Krausismo, collective biography, gender, mass media, and labor — and appended a bibliographical essay.

The 1990s saw a resurgence in populism studies, some retrospective and others contemporary. Torre (1992) assessed previous approaches, with emphasis on Laclau's discourse analysis and James's imputation of rationality to workers, plus added insights from Ecuador, about which he would later publish (Torre, 1997). Panfichi \& Sanborn (1995) examined the course of populism from Haya de la Torre to Fujimori, designating the latter a neopopulist. They stressed that although democratization proceeded through these leaders, it lacked strong institutional and procedural bases for true representation. Perruci (1995) focused on the 1989 election of Collor (and defeat of Lula) and the 1994 contest between Fernando Henrique Cardoso and Lula, which the former won. He noted that both Collor and Lula, while starkly different people, ran neopopulist campaigns that sought to bridge the gap between the electoral masses and their charismatic leaders. Cardoso won in 1994 because of his successful monetary reform and his moderate approach. Alan Knight (1998) reinforced the possibility of a rural variant of populism in Mexico and elsewhere.

The rise of Carlos Menem in Argentina attracted new attention from scholars. Jeremy Adelman (1992), already into Menem territory, re-tilled the fields of the origins of Peronismo in labor`s strengthening role in 1940s politics. Two years later (Adelman, 1994), he recapped the entire half-century of Argentine populism and anti-populism, seeing most post-1955 politics as failed attempts to recapture the magic of Perón's mid-1940s sociopolitical balancing act. The military regime and Raúl Alfonsín's disastrous administration virtually dismantled the state itself. He found that Menem, after running on a classic Peronist platform, willfully buried those planks as he assembled his own post-populist government. As many others before him, Adelman 
called this the "funeral of populism." José Nun (1994), on the other hand, after analyzing Menem's capture of the presidency, wrote that his administration, while breaking with some Peronist traditions, still represented the return of populism after a long absence.

Kenneth Roberts' (1995) and Kurt Weyland's (1996) deft analyses helped make sense of Menem's and Fujimori's successful resurrection of populist traditions while abandoning classic economic policies, allowing them to retain their broad appeal. They demonstrated that neopopulism and neoliberalism (which Menem, Collor, Fujimori, and others had embraced) enjoyed unexpected affinities. The former also sketched out a brief history of definitions in the field, identifying that begun by the Argentines as historical/sociological. This approach embraced the Stanford graduates mentioned above and many other U.S. authors. Another prominent line of analysis stemmed from Gramsci and Lacau, that focused on hegemony, leadermasses discourse, and authoritarian tendencies. Roberts (2007) urged future writers seek syntheses of these various definitions. He devised a very useful version: "top-down political mobilization of mass constituencies by personalistic leaders who challenge elite groups on behalf of an ill-defined pueblo, or 'the people." (p. 5)

\section{0s}

The years after 2000 brought further influences on populism studies. First, the appearance of the "pink tide," a set of leaders challenged the neo-populist mainstream. Comprising Hugo Chávez, Ivo Morales, Rafael Correa, Néstor Kirchner, Lula da Silva, and others, these men took the region in a decidedly leftward direction and in opposition to U.S. influence. Second, the 9/11 attack on the New York Trade Center towers thrust terrorist vulnerabilities into high relief and caused a shift in U.S. attention from the western hemisphere toward the Middle East. Simultaneously, the 1999 turnover of the Panama Canal lowered U.S. commitments to its 
traditional sphere of influence. Latin America no longer constituted a priority for the U.S. government.

After 2000, historians took a back seat to political scientists and sociologists regarding populism in the region. Some of the latter took up the data-gathering tasks the former relied upon, like Stépanie Rousseau’s (2009) account of the women's movement in Peru during the 1980s and especially under the Fujimori government in the 1990s. Her field work included interviews, documentary research, and participant observation. She concluded that Fujimori embraced women's issues and initiated programs to address them, yet his neopopulist methods restricted women's full achievement of citizenship. Kampwirth (2010) also probed women's participation in populist settings with a variety of studies by historians and others. Her chapters covered many periods since the 1930s and most countries, including Nicaragua between the Somozas and Daniel Ortega, Ecuador between Velasco Ibarra and Abdalá Bucarám, Brazil from Vargas to Kubitschek, Argentina during Perón's two presidencies, Mexico from the 1930s to the 1970s, and contemporary Peru and Bolivia. As can be expected, the book included a stunning variety of experiences and female protagonists, with valuable comparative analyses.

Building on the surge of interest in neopopulism, Ellner (2003) looked closely at Chávez and Fujimori and found that they bore many similarities in class support, discourse, status as outsiders, authoritarian tendencies, economic policies, party-building efforts, and relations with the United States. Still, he believed that Chávez had a higher likelihood of replicating the successes of his classic predecessors and of leaving a permanent legacy.

Chávez underwent deep but admiring scrutiny as a populist in Cannon (2009). This study contained nearly as much theory as empirical analysis and attempted a grand synthesis based on the early years of Chavismo, that he described as populism "deeply rooted in a radical, eclectic, 
socialist and Latin Americanist ideology." (p. 201) He saw the failure of liberal democracies, as well as impositions of neoliberalism and globalization, as motivating forces in the emergence of neopopulism. Like Ellner, he often counterposed Chávez and Fujimori, to the benefit of the former. His chapter 2 related the decline of governability under preceding presidents, leaving the door open to Chávez as a savior. Later chapters plumbed Chávez's ideologies, socioeconomic programs, democratic achievements, and foreign policies. Cannon stood firmly in the tradition of Gramsci and Laclau yet rejected criticism of Chávez as an autocrat. He offered one of the most wide-ranging analyses of populism in recent years.

For readers still hungry for Chavismo, Hawkins's (2010) book follows the discourse approach to accompany this neopopulist leftist, along lines he would later generalize to Latin America in Hawkins and Rovira Kaltwasser (2017) discussed below.

Laclau (2005) published a new grand theory of populism that skirted normative treatment and enveloped the globe. To synthesize a hugely complex philosophical tract, that I cannot do justice to here, his notion held that populism emerged when social antagonisms surfaced in a given society, became articulated as political demands, and led to the coalescence of an entity, "the people," to achieve them. He continued to stress the importance of discourse and rhetoric, though this constitutes only a fraction of his theory. He cited as examples of populist emergence the U.S. People's Party, Mao Zedong's communist movement, and Ataturk's Republican People's Party, among many others. His sweeping embrace only seldom invoked Latin American cases. Historians may wish to seek theoretical guidance elsewhere.

2010s

A special issue of International Labor and Working Class History featured a summary piece on workers and their unions under the military regimes of Argentina, Brazil, and Chile 
(Winn, 2018). While not focused on populism, the attendant articles reviewed the historical literature of the dictatorships and labor's roles in them, which in many ways flowed from the preceding populist era. These articles took a common approach and traced the historiography of the subject, harking back to Victor Alba's work in the 1950s and 60s.

David Doyle (2011) took another approach, using Roberts's definition, hypothesizing that public distrust in political institutions (especially parties) spawned the latest populist upsurges. He used data from Vanderbilt's Latinobarómetro and other databases to confirm his view that “contemporary populism is best understood as a consequence of the gradual erosion of trust in the institutions of liberal democracy." (p. 1451) Others would follow his lead.

A new edition of Populism in Latin America (Conniff, 2012) brought the chapters up to date and analyzed the rise of the pink tide and its challenges to neo-populism. Revised chapters identified several of these leaders as populists, e.g. Chávez, Correa, and Lula, for developing campaigns and relationships with the masses that harked back to their classic predecessors. Other authors designated these as radical populists, the third wave, or the populist left (Seligson, 2007; Barr, 2017). Whether these new actors constituted a second rebirth of populism, however, or its demise as a useful analytical tool, remained to be seen. Political scientists like Torre and Arnson (2013) and Weyland (2013) busied themselves to sort this out.

In recent years social scientists continued scrutinizing contemporary populism. Del Tronco (2013), using survey data from Latinobarómetro, probed feelings of voter confidence and expectations of accountability in several countries, finding that recent populists like Chávez may have eroded public confidence, especially when compared with liberal democratic administrations like Chile's concertación. This may have resulted from declining faith in institutions. Grigera (2017), after a thoughtful historical survey of the classic and neopopulist 
periods, took stock of the Lula and Kirchner governments. He fully factored in the pink tide phenomenon and labeled these two leaders as "pink tide neopopulists." Yet definitions of these cases continued their drift from earlier anchorages.

Carlos de la Torre and Cynthia Arnson (2013) assembled a very useful reader providing a snapshot of the field in the early 2010s. Their introduction and conclusion gave overviews of approaches and issues and nicely summarized the chapter contents. One author, historian Leslie Bethell, stuck to his discipline's methods in charting the trajectory of populism in Brazil from Vargas to Lula, but several others also attempted to embrace longer periods, like "from the Peróns to the Kirchners," "from APRA to Ollanta Humala," and "from the MNR to the MAS." Others focused on individual figures or moments in recent times. Kenneth Roberts's "Parties and Populism in Latin America" drew on his deep knowledge of the region's history and its literature. The volume revealed overarching tensions between political strategy and discourse, populism and democracy, popular inclusion versus authoritarianism, liberalism versus statist economics, and unmediated and mediated representation. Although these chapters offer a rich account of phenomena surrounding populism, they also remind us of the parable of the blind Hindu wisemen touching different parts of an elephant to determine its true nature.

Hawkins and Rovira Kathwasser (2017), while not historians, tackled the ideational/discursive/rhetorical definition of populism, understood as a "cosmic struggle between a reified 'will of the people' and a conspiring elite." (p. 514) They operationalized it by reading and coding the speeches of presidents in Argentina, Chile, and Peru throughout the $20^{\text {th }}$ century, happily including the reformers as well as classical subjects. They positively identified most of the likely suspects, excluded a few, and included several surprise candidates, like Juan Velasco Alvarado and Salvador Allende. Having shown the utility of their approach, they stood it up 
against others, like the economic, structural, and political-strategic to argue for multidimensional analysis that nonetheless recognizes the primacy of the "Manichaean worldview inherent in populism.” (p. 523)

Robert Barr (2017) offered what's likely the latest entry to the literature, a study of "third wave populism" that focused on Bolivia in the early $21^{\text {st }}$ century but made valiant attempts to generalize to ten other nations. Barr devoted 78 pages to "political and ideational" definitions before alighting on a simple one that populism "is a means of building and/or maintaining political power based on the mass mobilization of supporters using antiestablishment appeals and plebiscitarian linkages." (p. 116) He posited six causal factors for its emergence: "level of institutionalization of the party system, citizens' confidence in political institutions, and their perception of corruption," plus "level of economic misery, exposure to globalization, and social spending." (p. 120) Yet public anger also surfaced as a prime motivator of voters. For Bolivia, Barr covered the 1990s-to-mid-2010s with conventional data about the collapse of governmentas-usual, followed by the rise of Ivo Morales as a populist. For regional comparisons he built many indices relying on Latinobarómetro and perceptions of corruption, whose methodologies mercifully ended up in three appendices. Historians will likely skim over these dense analyses to peruse his thoughtful conclusions.

Barr's herculean efforts to survey definitions, synthesize his own, and then test his findings merit attention, perhaps as a last attempt to come to grips with a dominant topic in Latin American nations, one he concludes remains "fascinating and confounding." (p. 185)

A final entry in this essay, Silva and Rossi (2018), seemed to close the door on a halfcentury of studies of Latin American populism. Leading political scientists weighed in on the years from the late 1990s to the mid-2010s to examine what happened to popular sectors during 
the reign of neoliberalism, reactions to these policies, and what results flowed from them. The basic story, laid out in the introduction and conclusion, consisted of resistance to neoliberal disincorporation of the masses at first, then their second incorporation under the leaders of five "paradigmatic" nations: Argentina, Bolivia, Brazil, Ecuador, and Venezuela. The substantive chapters, grouped into sections on social movements, trade unions, and political parties, examined paired cases (Argentina and Brazil, Ecuador and Bolivia), followed by sui generis Venezuela. The editors stated that the book used a "historical analytic framework," yet only one of the authors (Ellner) earned a Ph.D. in history. None of the chapter titles mentioned populism, and the index contained only a handful of references to it, mostly in García-Guadilla's and Hellinger's chapters on Venezuela and Roberts' chapter on parties. The near absence of populism in this excellent collection leads one back to Paul Drake's thoughtful conclusion (“Requiem for Populism?”) in the Stanford authors' 1982 book: “Therefore it seems time to perform at least a checkup if not an autopsy on populism." (p. 217)

From this historian's point of view, since about 2000 the study of populism in the region fell mostly to social scientists writing articles or chapters rather than monographs. Their approaches emphasized theory over textual exegesis and paradigmatic cases over broad syntheses. Their occasional books often built on single-country studies fleshed out with definitional material and regional comparisons. The United States virtually disappeared as a player, except as a foil for the Washington Consensus. In fact, other concerns seemed to push aside human beings as historical subjects. Biography ended up replaced by sectors, institutions, parties, movements, critical junctures and the like. Unless some unforeseen development occurs, I believe that populism in Latin America has run its course as a topic of historical study. 
Even among social scientists, drift and backfill occurred as global shifts took place. Marx and Gramsci lost favor, yet theorists updated their earlier understandings to accommodate them. Paul Drake looked back over the nearly 40 years since writing "Requiem for Populism?" and experienced feelings of obsolescence due to shifts in our field from political to cultural history, to the dominance of rational choice and quantitative methods in political science, and to the decline of traditional interdisciplinary approaches blending history and the social sciences in Latin American area studies. I share his sentiments as I say adiós a populismo.

Acha, O. (2013). Latin American populism: Tentative reflections for a global historiographical perspective. Nuevo Mundo-Mundos Nuevos, 1.

Adelman, J. (1962). Reflections on Argentine Labour and the Rise of Perón. Bulletin of Latin American Research, 11, 243-259.

Adelman, J. (1994). Post-populist Argentina. New Left Review, 203, 65-91.

Alba, V. (1966). Populism and national awareness in Latin America. Lawrence, KS: University of Kansas Center for Latin American Studies.

Altman, W., Miranda Pacheco, M., Sala de Tourón, L., Winocur, M. (1983). El populismo en América Latina. Mexico: Universidad Nacional Autónoma de México.

Andrade, R. (1979). Perspectivas no estudo do populismo brasileiro. Encontros com a Civilização Brasileira, 7, 41-86.

Baquero, M. (2010). Populism and neo-populism in Latin America: Its legacy on political parties and political culture. Sociedade e Cultura, 13(2), 181-192.

Basurto, J. (1969). Populismo y movilización de masas en México durante el régimen cardenista. Revista Mexicana de Sociología, 31(4), 853-892.

Barr, R. (2017). The resurgence of populism in Latin America. Boulder, CO: Lynne Rienner.

Blanchard, P. (1977). A populist precursor: Guillermo Billinghurst. Journal of Latin American Studies, 9, 251-273.

Brito, V. L. A. (1978). Relações estado/sociedade no período populista. Revista Brasileira de Estudos Políticos, 46, 183-194. 
Camargo, A. (1979). Authoritarianism and populism: Bipolarity in the Brazilian Political system. In N. Aguiar (Ed.), The structure of Brazilian development (pp. 99-125). New Brunswick, NJ: Transaction Books.

Cannon, B. (2009). Hugo Chávez and the Bolivarian revolution: Populism and democracy in a globalised age. Manchester, UK: Manchester University Press.

Cardoso, F. H., \& Faletto, E. (1979). Dependency and development in Latin America. Berkeley, CA: University of California Press.

Carrizo de Muñoz, N. (1990). Neoliberalismo y neopopulismo en América Latina. El Debate Hoy, 1(1), 43-56.

Conniff, M. L. (1981). Urban politics in Brazil: The rise of populism, 1925-1945. Pittsburgh, PA: University of Pittsburgh Press.

Conniff, M. L. (Ed.). (1982). Latin American populism in comparative perspective. Albuquerque, NM: University of New Mexico Press.

Conniff, M. L. (Ed.). (1999). Populism in Latin America. Tuscaloosa, AL: University of Alabama Press.

Conniff, M. L. (Ed.). (2012). Populism in Latin America (2nd ed.). Tuscaloosa, AL: University of Alabama Press.

Debert, G. (1979). Ideología e populismo: A. De Barrios, M. Arraes, C. Lacerda, e L. Brizola. São Paulo: T. A. Queiroz.

Del Tronco, J. (2013). Desconfianza y Accountability: ¿Las causas del populismo en América Latina? Latin American Research Review, 48(2), 55.

Demmers, J., Fernández Jilberto, A., \& Hogenboom, B., (Eds.). (2001). Miraculous metamorphoses: The neoliberalisation of Latin American populism. London, UK, and New York, NY: Zed Books.

Dix, R. H. (1978). The varieties of populism: The case of Colombia. The Western Political Quarterly, 31(3), 334-51.

DiTella, T. (1965). Populismo y reforma en América Latina. Desarrollo económico, 4, 391-425.

Dornbusch, R., \& Edwards, S. (1991). The macroeconomics of populism in Latin America. Chicago, IL: University of Chicago Press.

Doyle, D. (2011). The legitimacy of political institutions: Explaining contemporary populism in Latin America. Comparative Political Studies, 44(11), 1447-1473. 
Drake, P. W. (1978). Socialism and populism in Chile, 1932-52. Urbana, IL: University of Illinois Press.

Ellner, S. (2003). The contrasting variants of the populism of Hugo Chávez and Alberto Fujimori. Journal of Latin American Studies, 35(1), 139-162.

French, J. D. (1988). Workers and the rise of Adhemarista populism in São Paulo, Brazil, 194549. Hispanic American Historical Review, 68(1), 1-43.

French, J. D. (1989). Industrial workers and the birth of the populist republic in Brazil, 19451946. Latin American Perspectives, 16(4), 5-27.

Gallaga, R. (1970). El populismo latinoamericano. Pensamiento Político, 15, 67-74.

Grigora, J. (2017). Populism in Latin America: Old and new populisms in Argentina and Brazil. International Political Science Review, 38(3), 441-455.

Hawkins, K. A. (2010). Venezuela's Chavismo and populism in comparative perspective. Cambridge: Cambridge University Press.

Hawkins, K. A., \& Rovira Kaltwasser, C. (2017). The ideational approach to populism. Latin American Research Review, 52(4), 513-528.

Ianni, O. (1968). O colapso do populismo no Brasil. Rio de Janeiro: Civilização Brasileira.

Ianni, O. (1975). La formación del estado populista en América. Mexico: Ediciones Era.

Jaguaribe, H. (1954). Que é o Ademarismo. Cadernos de nosso tempo, 139-49.

Jaguaribe, H. (1974). Brasil: Crise e alternativas. Rio de Janeiro: ZAHAR editores.

James, Daniel. (1985). Ideologia popular y resistência de classe: O peronismo e a classe operária, 1955-1960. Revista Brasileira de Historia, 5(10), 5-27.

Kampwirth, K. (2010). Gender and populism in Latin America: Passionate politics. University Park, PA: Pennsylvania State University Press.

Klaiber, J. L. (1989). Prophets and populists: Liberation theology, 1968-1988. Americas: A Quarterly Review of Inter-American Cultural History, 46(1), 1.

Knight, A. (1998). Populism and neopopulism in Latin America, especially Mexico. Journal of Latin American Studies, 30, 223-248.

Laclau, E. (1977). Politics and ideology in Marxist theory: Capitalism, fascism, populism. London, UK: NLB. 
Laclau, E. (1987). Populismo y la transformación del imaginario político en América Latina. Boletín de Estudios Latinoamericanos y del Caribe, 42, 25-38.

Laclau, E. (2005). On populist reason. London, UK: Verso.

Levitsky, S., \& Roberts, K. (2011). The resurgence of the Latin American left. Baltimore, MD: Johns Hopkins University Press.

Mackinnon, M. M., \& Perone, M. A. (Eds.) (1998). Populismo y neopopulismo en América Latina: El problema de la cenicienta. Buenos Aires: Eudeba.

Martz, J. D. (1980). The regionalist expression of populism: Guayaquil and the CFP, 1948-1960. Journal of Interamerican Studies and World Affairs, 22(3), 289-314.

Martz, J. D. (1983). Populist leadership and the party caudillo: Ecuador and the CFP, 1962-81. Studies In Comparative International Development, 18(3), 22-49.

Melo, J. M., (Ed.). (1981). Populismo e comunicação. São Paulo: Cortez Editora.

Mitchell, C. (1977). The legacy of populism in Bolivia: from the MNR to military rule. New York, NY: Praeger.

Mouzelis, N. (1985). On the concept of populism: Populist and clientelist modes of incorporation in semiperipheral polities. Politics \& Society, 14(3), 329-348.

Murmis, M., \& Portantiero, J. C. (1972). Estudios sobre los orígenes del peronismo (2nd ed). Buenos Aires: Siglo Vientiuno Argentina Editores.

Nun, J. (1994). Populismo, representación y menemismo. Sociedad, 5, 93-121.

Panfichi, A., \& Sanborn, C. (1995). Democracia y neopopulismo en el Perú contemporáneo. Márgenes, 8(13-14), 43-67.

Perruci, G. (1995). Neopopulism in Brazil's democratic consolidation: A comparative analysis. Austrian Journal of Development Studies, 11, 29-49.

Perruci, G., \& Sanderson, S. (1989) Presidential succession, economic crisis, and populist resurgence in Brazil. Studies in Comparative International Development, 24, 30-50.

Redclift, M. (1980). Agrarian populism in Mexico: the 'Via Campesina'. The Journal of Peasant Studies, 7(4), 492-502.

Roberts, K. M. (1995). Neoliberalism and the transformation of populism in Latin America: The Peruvian case. World Politics, 48(1), 82-116. 
Roberts, K. M. (2007). Latin America's populist revival. SAIS Review, 27(1), 3-15.

Rousseau, S. (2009). Women's citizenship in Peru: The paradoxes of neopopulism in Latin America. New York: Palgrave Macmillan.

Sanderson, S. (1981). Agrarian populism and the Mexican state: The struggle for land in Sonora. Berkeley,CA: University of California Press.

Schoultz, L. (1983). The populist challenge: Argentine electoral behavior in the postwar era. Chapel Hill, NC: University of North Carolina Press.

Seligson, M. (2007). The rise of populism and the left in Latin America. Journal of Democracy, 18(3), 81-95.

Silva, E., \& Rossi, F. M. (Eds.). (2018). Reshaping the political arena in Latin America: From resisting neoliberalism to the second incorporation. Pittsburgh, PA: University of Pittsburgh Press.

Skidmore, T. (1967). Politics in Brazil, 1930-1964: An Experiment in Democracy. Oxford, UK, and New York, NY: Oxford University Press.

Skidmore, T. E. (1978). The Economic Dimensions of Populism in Argentina and Brazil: A Case Study in Comparative Public Policy. New Scholar, 7(1-2), 129-166.

Soares, J. A. (1982) A frente do Recife e o governo do Arraes: nacionalismo em crise, 1955 1964. Rio: Paz e Terra.

Stein, S. (1980). Populism in Peru: The emergence of the masses and the politics of social control. Madison, WI: University of Wisconsin Press.

Torre, C. D. (1992). The ambiguous meanings of Latin American populisms. Social Research, $59(2), 385-414$.

Torre, C. D. (1997). Populism and democracy: Political discourses and cultures in contemporary Ecuador. Latin American Perspectives, 24(3), 12-24.

Torre, C. D. (2010). Populist seduction in Latin America: The Ecuadorian experience (2nd ed). Athens, OH: Ohio University Press.

Torre, C. D., \& Arnson, C. J. (Eds.). (2013). Latin American populism in the twenty-first century. Washington, DC: Woodrow Wilson Center Press/Baltimore, MD: Johns Hopkins University Press.

Touraine, A. (1987). Actores sociales y sistemas políticos en América Latina. Santiago, Chile: PREALC. 
Viguera, A. (1993). 'Populismo' y 'neopopulismo' en América Latina. Revista Mexicana de Sociología, 55(3), 49-66.

Vilas, C. M. (1988). El populismo latinoamericano: un enfoque estructural. Desarrollo Económico, 28, 323-352.

Vilas, C. M. (Ed.). (1995). La democratización fundamental: El populismo en América Latina. Mexico, DF: Consejo Nacional para la Cultura y las Artes.

Weffort, F. C. (1965). Política de massas. In O. Ianni, et al. (Eds.), Política e revolução social no Brasil (pp. 161-98). Rio: Civilização Brasileira.

Weffort, F. C. (1966). State and mass in Brazil. Studies in Comparative International Development, 2(12), 187-196.

Weffort, F. C. (1978). O populismo na política brasileira. Rio: Paz e Terra.

Weyland, K. (1996). Neopopulism and neoliberalism in Latin America: Unexpected affinities. Studies in Comparative International Development, 31(3), 3-31.

Weyland, K. (2001). Clarifying a contested concept: Populism in the study of Latin American politics. Comparative Politics, 34(1), 1-22.

Weyland, K. (2013). The threat from the populist left. Journal of Democracy, 24(3), 18-32.

Winn, P. (2018). Dictatorships and the worlds of work in the Southern Cone: Argentina, Brazil and Chile. International Labor and Working-Class History, 93, 5-7. 